\title{
Self-Organization and Physicochemical Properties of Aqueous Solutions of the Sodium Salt of Azosulphonate Calix[4]arene
}

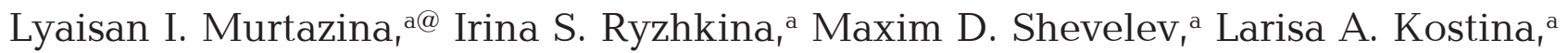 \\ Diana A. Sharapova, ${ }^{a}$ Zaliya V. Akhmetzyanova, ${ }^{b}$ Elena V. Popova, ${ }^{a}$ \\ Svetlana E. Solovieva, ${ }^{a, b}$ Igor S. Antipin, ${ }^{a, b}$ and Alexander I. Konovalov ${ }^{a}$
}

${ }^{a}$ Arbuzov Institute of Organic and Physical Chemistry, FRC Kazan Scientific Center, Russian Academy of Sciences, 420088

Kazan, Russia

${ }^{\mathrm{b}}$ Kazan Federal University, 420008 Kazan, Russia

@Corresponding author E-mail: LIMurt@yandex.ru

\begin{abstract}
The self-organization and physicochemical properties of aqueous solutions of the sodium salt of azosulfonate calix[4] arene (1) were studied in a wide range of concentrations $1 \cdot 10^{-10}-1 \cdot 10^{-1} \mathrm{M}$ using a complex of methods. It has been found that the solutions of macrocycle 1 are in fact complex disperse systems, the nature of disperse phase in which changes with dilutions - from micelles $\left(C M C=2.5 \cdot 10^{-2} \mathrm{M}\right)$ and premicellar aggregates $\left(1 \cdot 10^{-2}-1 \cdot 10^{-3} \mathrm{M}\right)$ of the size of $1 \mathrm{~nm}$ to supramolecular domains $\left(1 \cdot 10^{-3}-1 \cdot 10^{-6} \mathrm{M}\right)$ with sizes of tens and hundreds of $\mathrm{nm}$. Jointly using the methods of dynamic light scattering and UV spectroscopy it was shown for the first time that the nonlinear character of the concentration dependence of the optical absorbance $\left(A_{360}\right)$ in the concentration range $1 \cdot 10^{-6}-1.5 \cdot 10^{-5} \mathrm{M}$ is a result of the rearrangements of supramolecular domains of 1, accompanied by the transition from bi- to monomodal pattern of particles' size distribution, as well as by non-monotonic change in their size and ऊ-potential. It was established that molecules of $\mathbf{1}$ are not capable of photoisomerization of the azobenzene group, which may be due to steric hindrances to the process of isomerization of closely located azoarylsulfonate groups located on one side of the plane of macrocycle 1.
\end{abstract}

Keywords: Azosulphonate calix[4]arene, aqueous disperse systems, physicochemical properties.

\section{Самоорганизация и физико-химические свойства водных растворов натриевой соли азосульфонатного каликс[4]арена}

\author{
ᄉ. И. Муртазина, ${ }^{a}$ И. С. Рыжкина, ${ }^{a}$ М. А. Шевелев, ${ }^{a}$ А. А. Костина, ${ }^{a}$

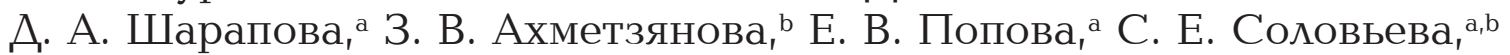 \\ И. С. Антипин, ${ }^{a, b}$ А. И. Коновалов ${ }^{a}$
}

\footnotetext{
${ }^{a}$ Институт органической и физической химии им. А.Е. Арбузова, ФИЦ Казанский научный центр РАН, 420088 Казань, Россия

${ }^{\mathrm{b}}$ Казанский федеральныцй университет, 420008 Казань, Россия

${ }^{\circledR}$ E-mail: LIMurt@yandex.ru
}

Комплексом методов в иироком интервале концентраций $1 \cdot 10^{-10}-1 \cdot 10^{-1}$ М изучена самоорганизация, физикохимические свойства водных растворов натриевой соли азосульфонатного каликс[4]арена (1). Найдено, что растворы макроцикла 1 представляют собой сложные дисперсные системы, дисперсной фазой в которых по мере разбавления являются супрамолекулярные структуры различной природы-мичеллы $\left(K K M=2.5 \cdot 10^{-2} M\right)$, предмицеллярные агрегаты $\left(1 \cdot 10^{-2}-1 \cdot 10^{-3} \mathrm{M}\right)$ размером около $1 \mathrm{Hм}$, а также супрамолекулярные домены $\left(1 \cdot 10^{-3}-\right.$ $1 \cdot 10^{-6}$ M) размером в десятки и сотни нм. Совместно методами динамического светорассеяния и УФспектроскопии впервые показано, что нелинейный вид концентрационной зависимости оптической плотности $\left(A_{360}\right)$ в области конщентраций $1 \cdot 10^{-6}-1.5 \cdot 10^{-5}$ М является следствием перестроек супрамолекулярных доменов 1, сопровождающихся переходом от би- кмономодальному размерному распределению частии, немонотонному 


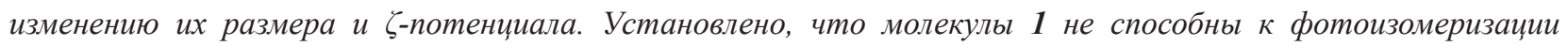
азобензольной группы, что может быть связано со стерическими препятствиями процессу изомеризации близко расположенных азоарилсульфонатных групп, находящихся по одну сторону от плоскости макроцикла 1.

Ключевые слова: Натриевая соль азосульфонатного каликс[4]арена, водные дисперсные системы, физикохимические свойства.

\section{Introduction}

Calixarenes are synthetically accessible macrocyclic phenols that model receptor, transport, and catalytic functions of a number of complex biomolecules. ${ }^{[1,2]}$ Calixarenes, even without distinct hydrophilic and hydrophobic regions, are capable of self-organization and the formation of supramolecular assemblies of various types. ${ }^{[1-5]}$ In the last decade, much attention has been paid to the study of the synthesis methods, properties and applications of azosulfonate calix[4] arenes (ASC) and their derivatives. ${ }^{[6,7]}$ Water-soluble ASC are promising compounds that may have photo-switching properties, ${ }^{[8,9]}$ which allows managing the self-organization and physicochemical properties of the substance in solution. However, the processes of self-organization and physicochemical properties of ASC solutions have not been systematically studied in a wide range of concentrations.

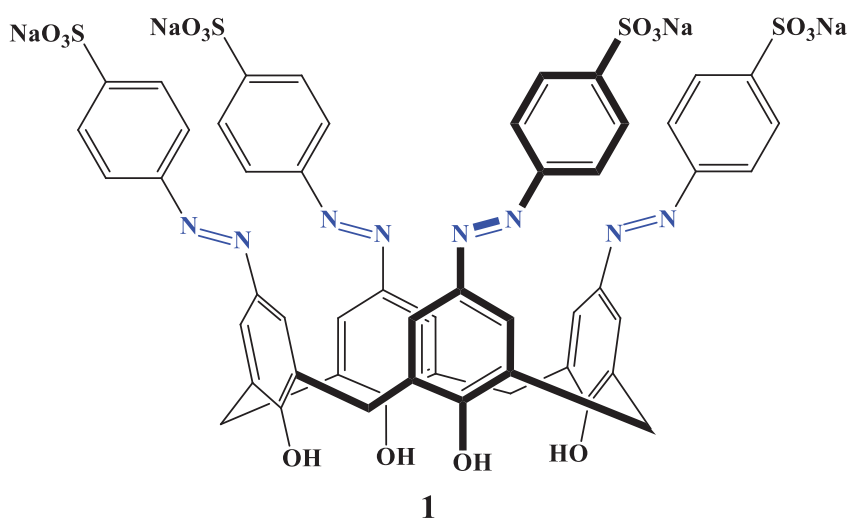

The aim of this work is to study self-organization and physicochemical properties of aqueous solutions of the sodium salt of azosulfonate calix[4]arene (1) in the concentration range $1 \cdot 10^{-10}-1 \cdot 10^{-1} \mathrm{M}$ using a complex of physicochemical methods (dynamic (DLS) and electrophoretic light scattering (ELS), tensiometry, conductometry, UV spectroscopy).

\section{Experimental}

Synthesis of sodium salt of para-(sulfophenylazo)calix[4] arene (1) was carried out based on published method ${ }^{[7]}$ with modification of yielding. The data of IR and ${ }^{1} \mathrm{H}$ NMR spectra of $\mathbf{1}$ corresponded to the previously published ones..$^{[7]}$

The self-organization and physicochemical properties of solutions of $\mathbf{1}$ in the range of dilutions corresponding to the calculated concentrations ranging from $1 \cdot 10^{-10}$ to $1 \cdot 10^{-1} \mathrm{M}$ were studied by dynamic (DLS) and electrophoretic (ELS) light scattering on a Zetasizer Nano ZSP analyzer (Malvern Instruments, Great Britain), UV spectroscopy (UV/Vis Cary 100 spectrophotometer,
Agilent, USA) using QS-SUPRASIL quartz cells $1 \mathrm{~cm}$ in length, conductometry (inoLab Cond Level 1 conductometer, WTW), tensiometry (high-precision Sigma 702 ET tensiometer (KSV Instruments)). All studies were carried out at $25 \pm 0.1{ }^{\circ} \mathrm{C}$.

The preparation and study of systems based on $\mathbf{1}$ was carried out using a fresh bidistilled water, specific conductivity of which was no more than $1.5 \mu \mathrm{Sm} / \mathrm{cm}$. The systems based on 1 were prepared by the method of successive decimal dilutions from an initial substrate's solution of concentration of $1 \cdot 10^{-1} \mathrm{M}^{[10]}$ The samples for the determination of the size (D), viz., average hydrodynamic diameter at the maximum of the distribution curve, and $\zeta$-potential were prepared from "dust-free" solutions (Iso-Disc N-25-4 Nylon disposable filters (Supelco, USA) were used). The solutions were stirred with an IKA lab dancer minishaker for $10 \mathrm{~s}$.

The molar absorption coefficient $(\varepsilon)$ in absorption band maxima was calculated by the equation $A=\varepsilon C l$, where $A$ is the absorbance at the band maximum. The statistically estimated relative error of measurement of $\varepsilon$ was $2 \%$.

Experimental data were processed using the standard programs of Excel software package, particle size measurement errors $-\leq 15 \%$, errors in the measurement of physicochemical properties $-\leq 3 \%$.

\section{Results and Discussion}

The presence of pre-organized hydrophobic aromatic fragments and hydrophilic $\mathrm{SO}_{3}^{-}$groups in molecules of $\mathbf{1}$ makes them potential analogues of anionic surfactant that can reduce surface tension at the "water-air" interface. The study of surface tension in the concentration range of $1 \cdot 10^{-10}-1 \cdot 10^{-1} \mathrm{M}$ confirmed this assumption (Figure 1). In the range of $1 \cdot 10^{-10}-1 \cdot 10^{-3} \mathrm{M}$, the values of surface tension $(\sigma)$ do not change, amounting to $70.5 \pm 1 \mathrm{mN} / \mathrm{m}$. The increase in concentration is accompanied by a decrease in the surface tension, reaching $57.0 \mathrm{mN} / \mathrm{m}$ at $1 \cdot 10^{-1} \mathrm{M}$. The critical micelle concentration (CMC) of macrocycle $\mathbf{1}$, which corresponds to the inflection point in the $\sigma=f(\lg C)$ dependence, is $2.5 \cdot 10^{-2} \mathrm{M}(\sigma=59.0 \mathrm{mN} / \mathrm{m})$, which is comparable to the CMC of sodium dodecyl sulfate (SDS), a typical anionic surfactant, which is equal to $8.3 \cdot 10^{-3} \mathrm{M} .^{[1]}$ For comparison, the CMC of alkylated $p$-sulfonatocalix[4] arenes ${ }^{[12]}$ the molecules of which also contain pre-organized hydrophilic and hydrophobic fragments, are in the range of (6-9) $10^{-4} \mathrm{M}$ with close $\sigma$ values equal to $53.0-57.0 \mathrm{mN} / \mathrm{m}$ at the $\mathrm{CMC}$ point. Consequently, the CMC of macrocycle 1 is approximately 30-40 times higher than that of the alkyl $p$-sulfonatocalix[4]arenes, which may be due to the lack of a hydrophobic region formed by $O$-alkyl substituents. Thus, macrocycle $\mathbf{1}$ is an anionic surfactant with less pronounced surface-active properties than the alkylated $p$-sulfonatocalix[4]arenes and SDS.

The study of the electrical conductivity $(\chi)$ of aqueous solutions of macrocycle 1 showed that upon dilution of the solution from $1 \cdot 10^{-1}$ to $1 \cdot 10^{-10}$, the specific conductivity 


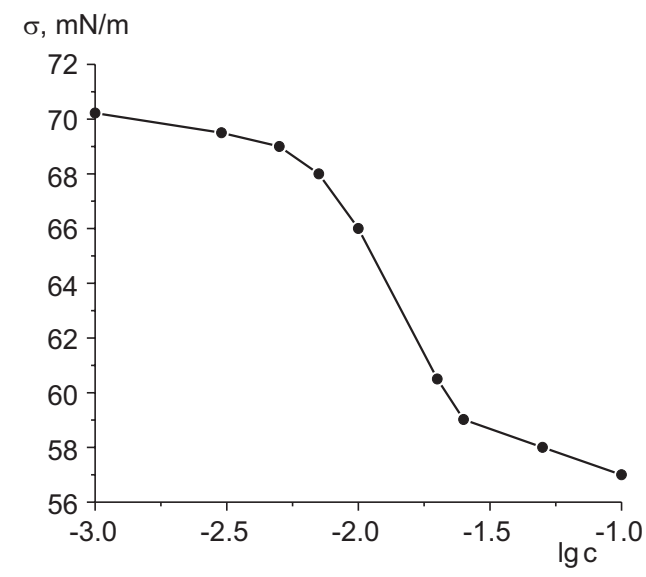

Figure 1. The surface tension isotherm of aqueous solutions of the macrocycle $1,25^{\circ} \mathrm{C}$.

varies non-monotonously from 6585 to $5.0 \mu \mathrm{S} / \mathrm{cm}$. Three inflection points are observed on the nonmonotonic concentration dependence plot of $\chi$ for aqueous solutions of 1: at $2.5 \cdot 10^{-2} \mathrm{M}$ (Figure 2, inset), which coincides with the system's $\mathrm{CMC}$ found by tensiometry, at $1 \cdot 10^{-3} \mathrm{M}$ and $1 \cdot 10^{-5} \mathrm{M}$ (Figure 2). Starting from a concentration of $1 \cdot 10^{-7} \mathrm{M}$ and below, the values of conductivity practically do not change, amounting to $\chi=5.0 \pm 0.5 \mu \mathrm{S} / \mathrm{cm}$, which is close to the $\chi$ value for distilled water.

As shown in, ${ }^{[12-17]}$ in addition to micelles, aqueous dispersed systems of amphiphilic calixarenes can form a dispersed phase of a different nature - molecular-water domains of hundreds of nanometers in size, consisting of molecules or ions of a solute and water structures, which usually form at concentrations of $1 \cdot 10^{-7}-1 \cdot 10^{-4} \mathrm{M}$. Domain restructuring is accompanied by non-monotonic changes in the physicochemical properties of the systems. In this case, the non-monotonic pattern of $\chi=f(\lg C)$ dependence suggests the formation of domains in solutions of macrocycle 1 at concentrations below CMC.

In order to study self-organization and establish the size and $\zeta$-potential of micelles and domains, solutions of macrocycle 1 were studied using the DLS and ELS meth-

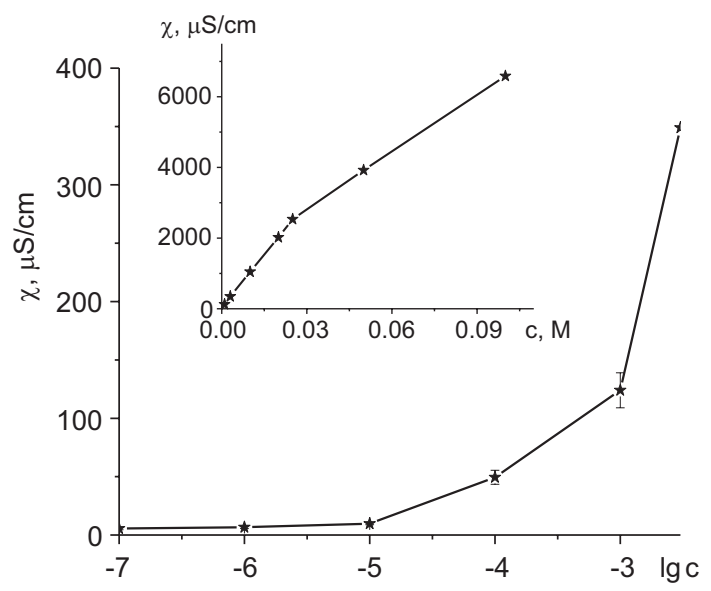

Figure 2. Electrical conductivity of aqueous solutions of the macrocycle 1 as a function of concentration, $25^{\circ} \mathrm{C}$. ods in the concentration range $1 \cdot 10^{-10}-1 \cdot 10^{-1} \mathrm{M}$. It was found that in the micellar concentration range $2.5 \cdot 10^{-2}-1 \cdot 10^{-1} \mathrm{M}$, i.e. at the $\mathrm{CMC}$ point and above, it is not possible to analyze solutions of 1 by the DLS and ELS methods due to the high polydispersity of the system.

In the premicellar region of $1 \cdot 10^{-3}-1 \cdot 10^{-2} \mathrm{M}$, a bimodal size distribution of scattering particles by intensity is observed ${ }^{[18,19]}$ (Figure 3a) with the particles of a size (d, $\mathrm{nm}$ ) of about $1 \mathrm{~nm}$ and hundreds of $\mathrm{nm}$ forming in the system. In contrast to the scattering distribution by intensity, the distribution by volume indicates the formation of only particles of about $1 \mathrm{~nm}$ in size in the system (Figure $3 b$ ). The obtained result indicates that small scattering particles significantly dominate in this concentration range. ${ }^{[20]}$ In the range of $1 \cdot 10^{-5}-1 \cdot 10^{-4} \mathrm{M}$, a bimodal size distribution is shown (Figure 3c,d). Particles of tens and hundreds of nm in size are formed in the system. Upon dilution of macrocycle 1 solutions in the range from $7 \cdot 10^{-6} \mathrm{M}$ to $1 \cdot 10^{-6} \mathrm{M}$, the monomodal size distribution of particles with a size of hundreds of nanometers is established (Figure 3e,f). Starting from a concentration of $1 \cdot 10^{-7} \mathrm{M}$ and below, scattering particles cannot be correctly determined by the DLS method. ${ }^{[20]}$

The ELS data suggests that as the concentration of macrocycle 1 decreases in the series $5 \cdot 10^{-3}, 1 \cdot 10^{-3}, 1 \cdot 10^{-4}, 1 \cdot 10^{-5} \mathrm{M}$, the negative $\zeta$-potential of the particles non-linearly decreases accordingly, $-75 \pm 3,-62 \pm 2,-31 \pm 2,-13 \pm 1 \mathrm{mV}$. At lower concentrations, the $\zeta$-potential cannot be reliably determined. The small size and high negative $\zeta$-potential of the particles in the premicellar region $5 \cdot 10^{-3}, 1 \cdot 10^{-3} \mathrm{M}$ (see Figure 1) suggests that they are premicellar aggregates, formed by the anions of the macrocycle 1 . Much smaller values of the $\zeta$-potential of particles of tens and hundreds of nanometers in the range of $1 \cdot 10^{-4}-1 \cdot 10^{-5} \mathrm{M}$ indicate that they are formed by the anions of macrocycle $\mathbf{1}$ and water structures, i.e. are molecular-water domains. With a decrease in concentration of $\mathbf{1}$ in the range of $1 \cdot 10^{-5}-1 \cdot 10^{-6} \mathrm{M}$, domains of only hundreds of nanometers in size are formed, containing, probably, mainly structured water, for which the $\zeta$-potential is not determined. Considering the data on the size and $\zeta$-potential of particles, as well as the concentration dependences of surface tension and conductivity, it can be considered that aqueous solutions of macrocycle 1 in the concentration range $1 \cdot 10^{-6}-1 \cdot 10^{-1} \mathrm{M}$ are complex disperse systems in which a disperse phase of different nature - anion micelles, small premicellar aggregates of about $1 \mathrm{~nm}$ in size, as well as supramolecular domains of tens and hundreds of nanometers in size, consisting of anions of macrocycle $\mathbf{1}$ and water structure - is formed under dilution.

Previously, when studying self-organization and UV spectra of aqueous systems of melaphen in the concentration range $1 \cdot 10^{-6}-1 \cdot 10^{-4} \mathrm{M}$, a nonlinear change in the molar absorption coefficient $(\varepsilon)$ with a decrease in substance concentration due to the formation of molecular-water domains of hundreds of $\mathrm{nm}$ in size was shown for the first time.

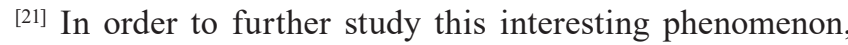
and to establish the relationship between the rearrangement of molecular-water domains and changes in the spectral properties of the dispersed system, solutions of $\mathbf{1}$ were jointly studied by the methods of DLS and UV spectroscopy in the range of $1 \cdot 10^{-6}-1.5 \cdot 10^{-5} \mathrm{M}$, which is characterized by the transition from bi- to monomodal size distribution 

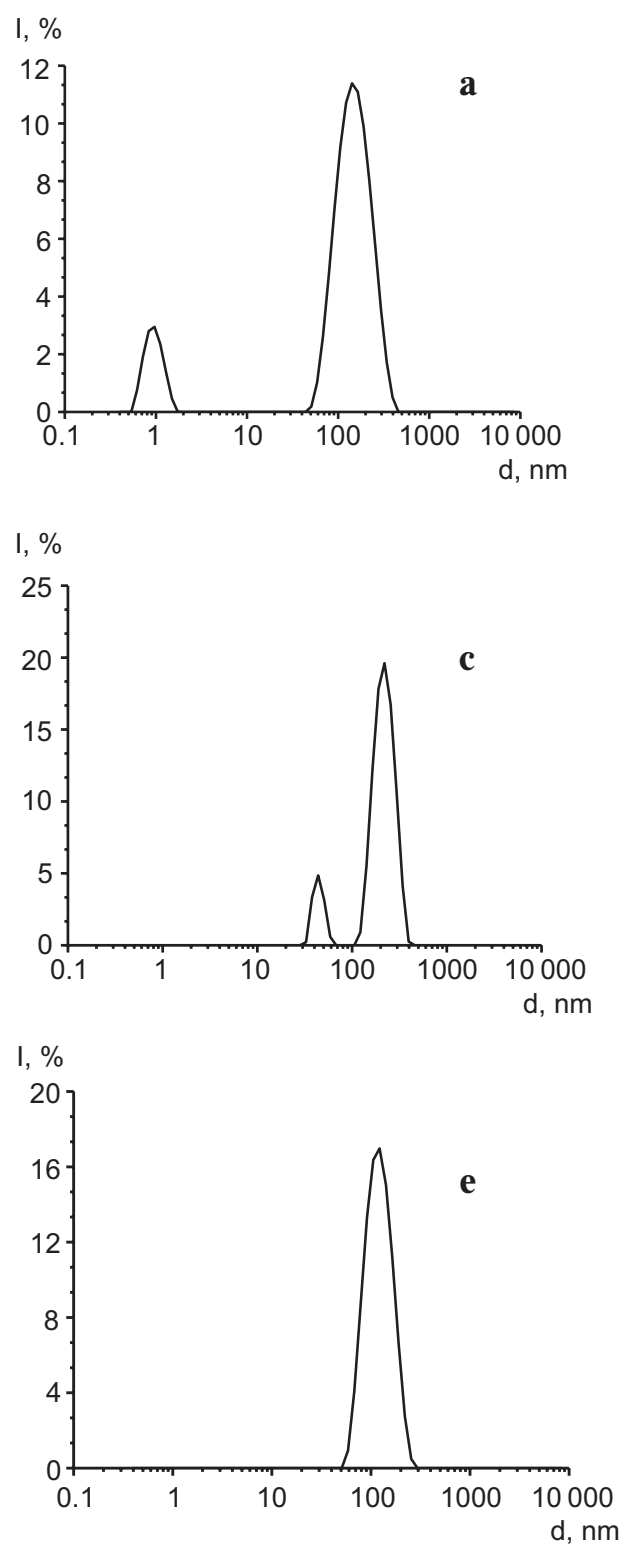
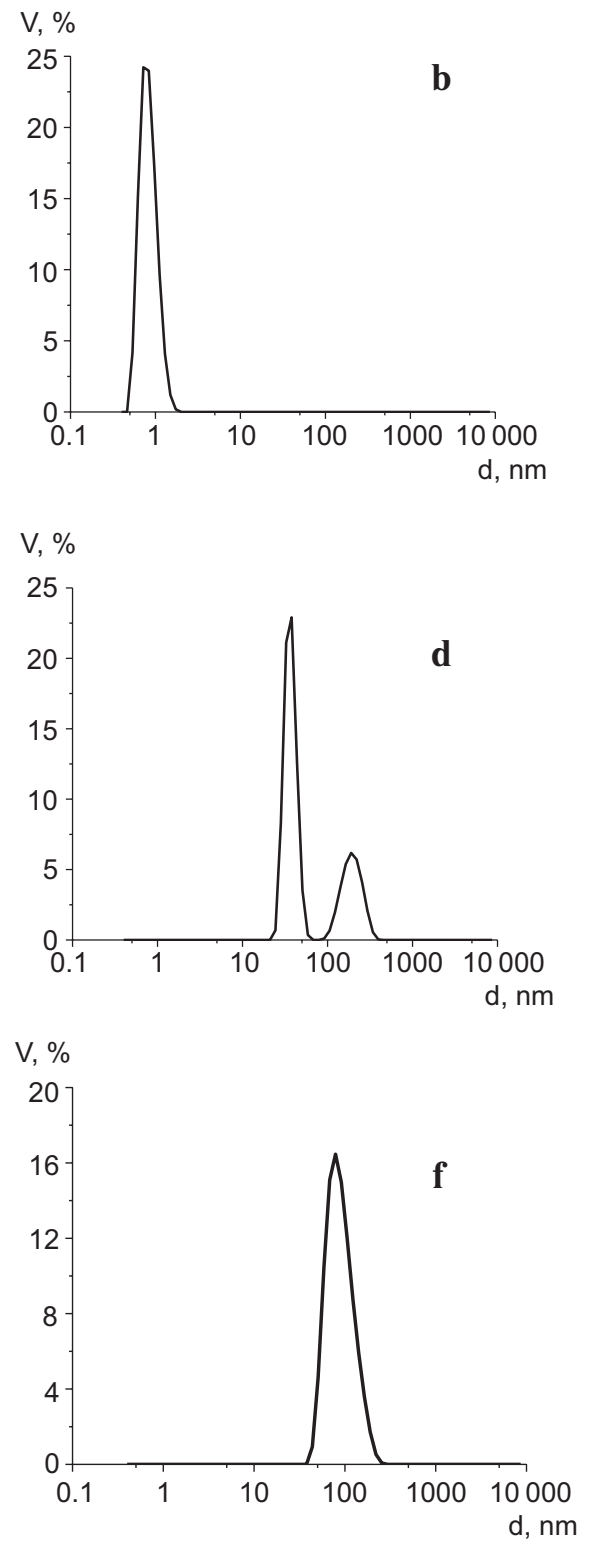

Figure 3. The size distribution of scattering particles in the scale of intensity $(a, c, e)$ and volume $(b, d, f)$ in the system based on the macrocycle 1 at concentrations of $1 \cdot 10^{-2}(\mathrm{a}, \mathrm{b}), 1 \cdot 10^{-4}(\mathrm{c}, \mathrm{d}), 1 \cdot 10^{-6}(\mathrm{e}, \mathrm{f}) \mathrm{M}$ at $25^{\circ} \mathrm{C}$, obtained by the DLS method.

of domains, nonmonotonic change in their size (Figure 4, curve 1) and the absence of the $\zeta$-potential.

In the UV spectrum of an aqueous solution of $\mathbf{1}$, there are two most intense absorption bands with maxima at 265 and $360 \mathrm{~nm}$, which correspond to the electronic transitions of the aromatic and azobenzene groups (Figure 5). An analysis of the UV absorption spectra of solutions 1 in the concentration range under study revealed the presence of a nonlinear dependence $A=f(C)$ at the maxima of these bands (Figure 5, inset) and, as a consequence, a change in the molar absorption coefficient ( $\varepsilon$ ). On the $A=f(C)$ dependences, two inflection points were found at $2 \cdot 10^{-6}, 1 \cdot 10^{-5} \mathrm{M}$, in the vicinity of which $\varepsilon$ changes dramatically (Figure 4 , curve 2 ).

A comparison of the nonmonotonic concentration dependences of $d$ and $\varepsilon$ at the maximum of the absorption band at $360 \mathrm{~nm}$ indicates their interconnection (Figure 4). In the range of $1.5 \cdot 10^{-5}-1 \cdot 10^{-5} \mathrm{M}$ and below, the transition from the bimodal size distribution of particles to monomodal

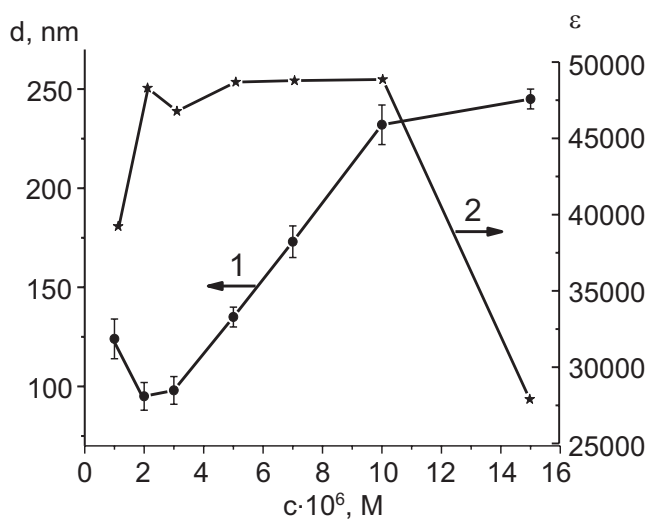

Figure 4. The dependence of the size of particles (d) formed in aqueous solutions of the macrocycle 1 (1), and the molar absorption coefficient $(\varepsilon)(2)$ on the concentration, $25^{\circ} \mathrm{C}$. 
one occurs with the formation of domains, consisting mainly of water structures, which in the range of $3 \cdot 10^{-6}-1 \cdot 10^{-6} \mathrm{M}$ undergo restructuring, leading to their consolidation. It is in these concentration intervals that $\varepsilon$ first increases from 27900 to $48700\left(1.5 \cdot 10^{-5}\right.$ and $1 \cdot 10^{-5} \mathrm{M}$, respectively), maintaining constancy to $5 \cdot 10^{-6} \mathrm{M}$, and then non-monotonously falling to 39230 at $1 \cdot 10^{-6} \mathrm{M}$. Thus, the nonlinear change in optical absorbance in the dispersed system of macrocycle 1 in the region of $1 \cdot 10^{-6}-1.5 \cdot 10^{-5} \mathrm{M}$ is a consequence of the process of rearrangement of the dispersed phase molecular-water domains.

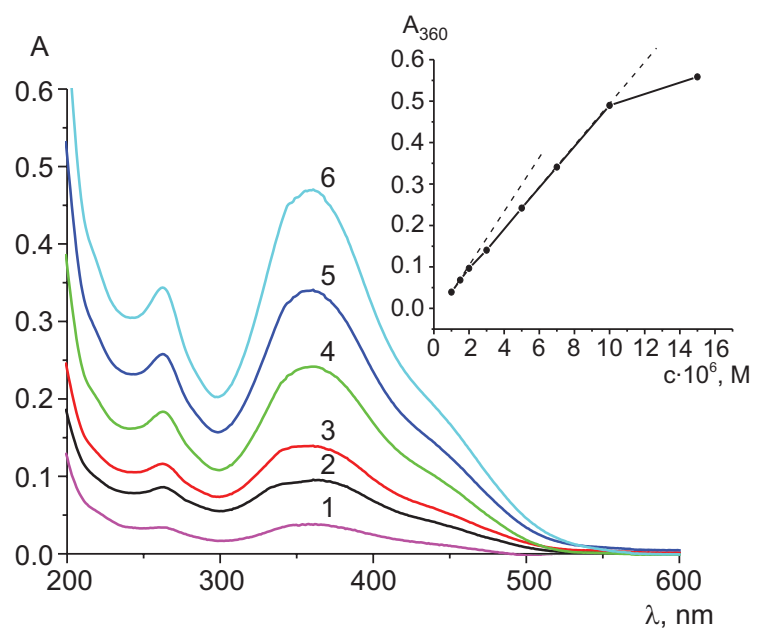

Figure 5. Absorption spectra of aqueous systems based on macrocycle 1 (1) $1 \cdot 10^{-6}$, (2) $2 \cdot 10^{-6}$, (3) $3 \cdot 10^{-6}$, (4) $5 \cdot 10^{-6}$, (5) $7 \cdot 10^{-6}$, (6) $1 \cdot 10^{-5} \mathrm{M}$. Insert: Absorbance at $360 \mathrm{~nm}\left(A_{360}\right)$ of aqueous systems based on 1 as a function of concentration, $25^{\circ} \mathrm{C}$.

It was previously shown ${ }^{[6]}$ that under UV irradiation with a wavelength of $254 \mathrm{~nm}(8 \mathrm{mV})$ of solutions of thiacalix[4]arenes in the stereoisomeric form of 1,3-alternate, containing an azoaryl group, photoisomerization around $\mathrm{N}=\mathrm{N}$ bond occurs in a 30 minutes period. To study the photoisomerization of the azo-group in macrocycle $\mathbf{1}$, which is in the cone conformation, the solutions of this compound were irradiated under similar conditions ${ }^{[5]}$ in the concentration range $1 \cdot 10^{-3}-1 \cdot 10^{-5} \mathrm{M}$. Comparison of the UV spectra of the solutions and the size distributions by intensity before and after irradiation throughout the studied range of concentrations and irradiation time did not reveal significant differences. Thus, macrocycle $\mathbf{1}$ is not capable of photoisomerization of the azo-group, which may be due to steric hindrances to the isomerization process due to the azoarylsulfonate groups closely spaced on one side of the macrocycle plane.

\section{Conclusions}

Self-organization and physicochemical properties of aqueous solutions of the sodium salt of azosulfonate calix[4]arene (1) were studied by a complex of methods in a wide range of concentrations $1 \cdot 10^{-10}-1 \cdot 10^{-1} \mathrm{M}$. It was found that solutions of macrocycle $\mathbf{1}$ are complex dispersed systems, the dispersed phase in which are supramolecular structures of various nature, changing with dilution - micelles $\left(\mathrm{CMC}=2.5 \cdot 10^{-2} \mathrm{M}\right)$, premicellar aggregates $\left(1 \cdot 10^{-2}-1 \cdot 10^{-3} \mathrm{M}\right)$ about $1 \mathrm{~nm}$ in size, and supramolecular domains $\left(1 \cdot 10^{-3}-1 \cdot 10^{-6} \mathrm{M}\right)$ of tens and hundreds of $\mathrm{nm}$ in size. It was shown for the first time by the jointly using methods of dynamic light scattering and UV spectroscopy that the nonlinear form of the concentration dependence of the optical absorbance $\left(A_{360}\right)$ in the region of $1 \cdot 10^{-6}-1.5 \cdot 10^{-5} \mathrm{M}$ is a consequence of rearrangements of supramolecular domains of $\mathbf{1}$, accompanied by a transition from bi- to monomodal size particle distribution, non-monotonic change in their size and $\zeta$-potential. It has been established that molecules of $\mathbf{1}$ are not capable of photoisomerization of the azobenzene group, which may be due to steric hindrances to the isomerization process caused by closely located azoarylsulfonate groups located on one side of the plane of macrocycle $\mathbf{1}$.

Author contribution. L.I. Murtazina and I.S. Ryzhkina participated in the justification of physico-chemical methods of research and analysis of the results, as well as in the writing of the manuscript M.D. Shevelev carried out the experiment to study the self-organization of aqueous solutions 1. L.A. Kostina carried out the experiment to study the physicochemical properties of aqueous solutions 1. D.A. Sharapova carried out the experiment to study the UV spectra of aqueous solutions 1. Z.V. Akhmetzyanova, E.V. Popova, S.E. Solovieva synthesized and characterized of macrocycle 1. The idea and supervision of the work belong to I.S. Antipin and A.I. Konovalov. All the authors have discussed the results and contributed to the final manuscript.

Acknowledgements. The work was done with the financial support of the Presidium of the Russian Academy of Sciences (Program No. 14) and was partially funded by subsidies allocated to the Kazan Federal University for state support in the field of scientific activities (4.1493.2017/6.7).

\section{References}

1. Asfari Z., Bohmer V., Harrowfield J., Vicens J. Calixarenes 2001. Dordrecht-Boston-London: Kluwer Academic Publishers, 2001. 683 p.

2. Calixarenes and Beyond (Neri P., Sessler J.L., Wang M.-X., Eds.) New York: Springer, 2016. 1053 p.

3. Muravev A., Solovieva S., Kochetkov E., Mel'nikova N., Safiullin R., Kadirov M., Latypov Sh., Antipin I., Konovalov A. Macroheterocycles 2013, 6, 302-307.

4. Solovieva S.E., Safiullin R.A., Kochetkov E.N., Melnikova N.B., Kadirov M.K., Popova E.V., Antipin I.S., Konovalov A.I. Langmuir 2014, 30, 15153-15161.

5. Ryzhkina I.S., Kiseleva Yu.V., Murtazina L.I., Solovieva S.E., Manin N.G., Konovalov A.I. Macroheterocycles 2017, 10, 190-195.

6. Ovsyannikov A.S., Akhmetzyanova Z.V., Allahverdilli G.R., Nougmanov R.I., Solovieva S.E., Antipin I.S., Konovalov A.I. Macroheterocycles 2018, 11, 173-180.

7. Kashapov R.R., Bekmukhametova A.M., Zakharova L.Ya., Akhmetzyanova Z.V., Popova E.V., Solovieva S.E., 
Antipin I.S., Konovalov A.I. Macroheterocycles 2017, 10, 454-459.

8. Yushkova E.A., Zaikov E.N., Stoikov I.I., Antipin I.S. Russ. Chem. Bull. Int. Ed. 2009, 58, 101-107.

9. Shao L., Hua B., Yang J., Yu G. Chem. Commun. 2016, 52, 6573-6576.

10. Konovalov A.I., Ryzhkina I.S. Russ. Chem. Bull. 2014, 60(1), $1-14$.

11. Gennis R.B. Biomembranes. Molecular Structure and Function. New York: Springer-Verlag, 1989. 533 p.

12. Ryzhkina I.S., Kiseleva Yu.V., Solov'eva S.E., Pilishkina L.M., Konovalov A.I., Valitova Y.N. Russ. Chem. Bull. Int. Ed. 2009, 58, 2506-2511.

13. Ryzhkina I.S., Kiseleva Yu.V., Mishina O.A., Murtazina L.I., Sudakova S.N., Pod'yachev S.N., Konovalov A.I. Dokl. Phys. Chem. 2013, 453, 264-269.

14. Ryzhkina I.S., Kiseleva Yu.V., Mishina O.A., Masagutova E.M., Sergeeva S.Yu., Sudakova S.N., Pod'yachev S.N., Kon- ovalov A.I. Russ. Chem. Bull. Int. Ed. 2014, 63, 1399-1408.

15. Gall L.N., Gall N.R. Dokl. Phys. Chem. (Engl. Transl.) 2015, 461(2), 92-95.

16. Samal S., Geckeler K. Chem. Commun. 2001, 2224-2225.

17. Kononov L.O. RSC Adv. 2015, 5, 46718-46734.

18. Ryzhkina I.S., Kiseleva Yu.V., Mishina O.A., Murtazina L.I., Litvinov A.I., Kadirov M.K., Konovalov A.I. Russ. Chem. Bull. Int. Ed. 2015, 64, 579-589.

19. Ryzhkina I.S., Sergeeva S.Yu., Safiullin R.A., Ryzhkin S.A., Margulis A.B., Murtazina L.I., Timosheva A.P., Chernova A.V., Kadirov M.K., Konovalov A.I. Russ. Chem. Bull. Int. Ed. 2016, 65, 1505-1513.

20. Zetasizer Nano Series. User Manual, Malvern Instruments Ltd, UK, Malvern, 2008.

21. Konovalov A.I., Ryzhkina I.S., Murtazina L.I., Timosheva A.P., Shagidullin R.R., Chernova A.V., Avvakumova L.V., Fattakhov S.G., Russ. Chem. Bull. Int. Ed. 2008, 57, 12071214. 